\title{
COMPARISON OF SEVOFLURANE WITH HALOTHANE FOR ENDOTRACHEAL INTUBATION IN PAEDIATRIC PATIENTS
}

\author{
Umesh Uttamrao Deshmukh1, Agale Sangita Manikrao², Deshpande Satish $G^{3}$
}

${ }_{1}^{1}$ Assistant Professor, Department of Anaesthesiology, Government Medical College, Latur, Maharashtra. ${ }^{2}$ Assistant Professor, Department of Anaesthesiology, Government Medical College, Latur, Maharashtra. 3 Professor and HOD, Department of Anaesthesiology, Government Medical College, Latur, Maharashtra.

\section{ABSTRACT}

In paediatric patients, smooth induction with rapid endotracheal intubation without morbidity and mortality is of prime importance. Many of the inhalational anaesthetic agents have been tried for this purpose. In the present study, Sevoflurane due to its high potency, rapid induction, excellent intubating conditions with haemodynamic stability was compared with Halothane in paediatric patients. In the present study, 60 paediatric patients of ASA grade I and II of either sex were divided into 2 equal groups of 30 each according to inhalational anaesthetic agent used for induction of anaesthesia. In group S, Sevoflurane $8 \%$ and group $\mathrm{H}$ Halothane 3\% were used for induction of anaesthesia with Nitrous oxide/oxygen mixture on Boyles' anaesthesia machine. All patients received Inj. Glycopyrrolate $5-8 \mu \mathrm{gm} / \mathrm{kg}$ and inj. Midazolam $0.25 \mu \mathrm{gm} / \mathrm{kg}$ as premedication 10 minutes prior to the induction of anaesthesia. It was observed that mean induction time in group S was $210 \pm 17$ secs. and in Group H was $262 \pm 21$ secs. Sevoflurane has low blood/gas co-efficient of 0.69 as compared to Halothane 2.5, so quicker induction time with Sevoflurane as compared to Halothane. In group S, $90 \%$ of patients had excellent intubating conditions, $7 \%$ good, and 3\% had fair while in group $\mathrm{H} 84 \%$ had excellent intubating conditions, $13 \%$ had good, and $3 \%$ had fair intubating conditions. During intubation, mean pulse rate decreased significantly in both groups and increased after intubation. The decrease in pulse rate was comparatively less in group $S$ than group $\mathrm{H}$ and also there was significant increase in pulse rate after intubation in both groups. Similar changes were observed with mean systolic blood pressure and mean arterial pressure in both groups. Thus, Sevoflurane provided better cardiovascular stability during and after intubation as compared to Halothane. We observe that, Sevoflurane due to its cardiovascular stability, smooth induction, and excellent intubating conditions maybe preferred over Halothane in paediatric patients for endotracheal intubation.

\section{KEYWORDS}

Sevoflurane, Halothane, Smooth Induction, Rapid Intubation, Paediatric Patients.

HOW TO CITE THIS ARTICLE: Deshmukh UU, Manikrao AS, Satish GD. Comparison of sevoflurane with halothane for endotracheal intubation in paediatric patients. J. Evolution Med. Dent. Sci. 2016;5(69):5025-5029, DOI: 10.14260/jemds/2016/1141

\section{INTRODUCTION}

Introduction of newer anaesthetic agents and inhalation agents have refined and improved the anaesthetic practice. Endotracheal intubation is mandatory for providing safe protected airway and IPPV during general anaesthesia for operative procedures. Smooth endotracheal intubation is necessary to avoid bucking and coughing during laryngoscopy and endotracheal intubations and related complications of aspiration of gastric contents resulting morbidity and mortality.

In paediatric patients for smooth induction and rapid endotracheal intubation, halogenated hydrocarbon inhalational anaesthetic agents are being tried by so many practicing anaesthesiologists. Halothane was synthesised in 1951 and was introduced for clinical use in 1956. Halothane has tendency to enhance the dysrhythmogenic effects of epinephrine, which led to search of new inhalational agents. In this series, Methoxyflurane, Enflurane, Isoflurane were tried, but were not so popular. Then, Sevoflurane was introduced.

Halothane has been used worldwide for many years as it provides smooth induction and good intubating conditions

Financial or Other, Competing Interest: None.

Submission 07-05-2016, Peer Review 13-08-2016,

Acceptance 20-08-2016, Published 29-08-2016.

Corresponding Author:

Dr. Umesh Uttamrao Deshmukh,

"Torana" Nivas,

Datta Krupa Housing Society,

Old Ausa Road, Latur-413512,

Maharashtra.

E-mail: apexbeat32@yahoo.co.in

DOI: $10.14260 /$ jemds/2016/1141 with some drawbacks of myocardial depression and arrhythmias. Sevoflurane is non-pungent and with rapid increase in alveolar concentration makes it an excellent choice for rapid and smooth induction in paediatric patients. It has rapid onset of action within 1-3 minutes in 4-8\% concentration with more rapid emergence.

In view of these properties, the present study was undertaken to evaluate the efficacy of Sevoflurane for smooth induction and rapid endotracheal intubation with haemodynamic stability as compared to Halothane in paediatric patients.

\section{MATERIAL AND METHODS}

The present study was undertaken in 60 paediatric patients of age range 3 months-3 years of ASA grade I and II. The weight range was 3-12 kg. Sampling method used was double-blind randomised study. The paediatric patients with severe systemic diseases of renal, cardiovascular, respiratory, hepatic, and central nervous system were excluded from the study. All patients were preanaesthetically evaluated for fitness of anaesthesia and informed valid consent was obtained from parents. These patients were divided into 2 equal groups of 30 patients each according to inhalational induction agent used for endotracheal intubation. Sevoflurane group was labelled as Group S and Halothane group as Group $\mathrm{H}$.

Preoperatively, baseline pulse rate, blood pressure, and $\mathrm{O}_{2}$ saturation were noted. All patients were premedicated with Inj. Glycopyrrolate 5-8 $\mu \mathrm{gm} / \mathrm{kg}$ and inj. Midazolam 0.25 $\mu \mathrm{gm} / \mathrm{kg}$ IV 10 minutes prior to induction. Induction of anaesthesia was performed with $\mathrm{N}_{2} \mathrm{O}$ /Oxygen and either Halothane or Sevoflurane on mask with Boyles' anaesthesia 
machine. Endotracheal intubation was performed under 6-8\% Sevoflurane or $2-3 \%$ Halothane slowly incremental inhalation.

The quality of endotracheal intubation was assessed as ease of laryngoscopy, vocal cord position, coughing, or bucking on laryngoscopy and intubation, jaw relaxation, and response of body movements. The scoring system was used as devised by Helbo-Hausen and Trap-Anderson (1998) ${ }^{1}$ and revised by Steyn et al (1998). ${ }^{2}$

Anaesthesia was continued and maintained with $\mathrm{N}_{2} \mathrm{O}$, Oxygen, Halothane, or Sevoflurane on controlled ventilation. All patients were monitored for changes in pulse rate, blood pressure (systolic, diastolic, and mean pressure) intraoperatively, after premedication, during intubation, after intubation and 1, 2, 3 minutes after intubation. At the end of operative procedure, inhalational anaesthetic agent was tapered and extubation was done after complete recovery. These patients were also observed in recovery room for any related complications.

\section{Statistical Analysis}

The chi-square test was used for non-parametric data and students ' $t$ ' test for parametric data.

\section{Scoring System for Intubating Conditions:}

\begin{tabular}{|c|c|c|c|c|}
\hline \multirow{2}{*}{ Criteria } & \multicolumn{4}{|c|}{ Score } \\
\cline { 2 - 5 } Laryngoscopy & Easy & Fair & Difficult & Impossible \\
\hline Vocal cords & Open & Moving & Closing & Closed \\
\hline $\begin{array}{c}\text { Coughing } \\
\text { Jaw }\end{array}$ & None & Slight & Moderate & Severe \\
\hline $\begin{array}{c}\text { Limb } \\
\text { movement }\end{array}$ & Complete & Slight & Stiff & Rigid \\
\hline \multicolumn{5}{|c|}{ Helbo-Hansen } \\
\hline
\end{tabular}

\begin{tabular}{|c|c|c|c|c|}
\hline \multirow{2}{*}{ Criteria } & \multicolumn{4}{|c|}{ Score } \\
\cline { 2 - 5 } $\begin{array}{c}\text { Jaw } \\
\text { relaxation }\end{array}$ & Poor & Minimal & Moderate & Good \\
\hline $\begin{array}{c}\text { Vocal cord } \\
\text { position }\end{array}$ & Closed & Closing & Moving & Open \\
\hline $\begin{array}{c}\text { Reaction to } \\
\text { intubation }\end{array}$ & $\begin{array}{c}\text { Severe } \\
\text { Coughing }\end{array}$ & $\begin{array}{c}\text { Mild } \\
\text { Coughing }\end{array}$ & $\begin{array}{c}\text { Slight } \\
\text { Movements }\end{array}$ & none \\
\hline \multicolumn{5}{|c|}{ Cooper } \\
\hline
\end{tabular}

\begin{tabular}{|c|c|}
\hline Intubating Condition & Total Score \\
\hline Excellent & $8-9$ \\
\hline Good & $6-7$ \\
\hline Fair & $3-5$ \\
\hline Poor & $0-2$ \\
\hline
\end{tabular}

\section{RESULTS}

\begin{tabular}{|c|c|c|c|c|}
\hline \multirow{2}{*}{$\begin{array}{c}\text { Age in } \\
\text { Months }\end{array}$} & \multicolumn{2}{|c|}{$\begin{array}{c}\text { Sevoflurane } \\
\text { Group S }\end{array}$} & $\begin{array}{c}\text { Halothane Group } \\
\text { G }\end{array}$ \\
\cline { 2 - 5 } & $\begin{array}{c}\text { No. of } \\
\text { Patients }\end{array}$ & $\%$ & $\begin{array}{c}\text { No. of } \\
\text { Patients }\end{array}$ & $\%$ \\
\hline $3-6$ & 1 & 3 & 4 & 13 \\
\hline $7-12$ & 9 & 30 & 8 & 27 \\
\hline $13-18$ & 4 & 13 & 4 & 13 \\
\hline $19-24$ & 7 & 24 & 4 & 13 \\
\hline $25-30$ & 3 & 10 & 8 & 27 \\
\hline $31-36$ & 6 & 20 & 2 & 8 \\
\hline Total & $\mathbf{3 0}$ & \multicolumn{3}{|c}{} \\
\hline \multicolumn{7}{|c|}{ Table I: Showing Age Distribution } & \\
\hline
\end{tabular}

\begin{tabular}{|c|c|c|c|c|}
\hline Gender & Group S & Group H \\
\hline & No. of Patients & $\%$ & No. of Patients & $\%$ \\
\hline Male & 20 & 67 & 23 & 77 \\
\hline Female & 10 & 33 & 07 & 23 \\
\hline Total & $\mathbf{3 0}$ & & $\mathbf{3 0}$ & \\
\hline \multicolumn{4}{|c|}{ Table II: Showing Sex Distribution } \\
\hline
\end{tabular}

\begin{tabular}{|c|c|c|c|c|}
\hline \multirow{2}{*}{$\begin{array}{c}\text { Weight } \\
\text { Range in Kg }\end{array}$} & \multicolumn{2}{|c|}{$\begin{array}{c}\text { Sevoflurane } \\
\text { Group S }\end{array}$} & \multicolumn{2}{c|}{$\begin{array}{c}\text { Halothane Group } \\
\text { G }\end{array}$} \\
\cline { 2 - 5 } & $\begin{array}{c}\text { No. of } \\
\text { Patients }\end{array}$ & $\mathbf{\%}$ & $\begin{array}{c}\text { No. of } \\
\text { Patients }\end{array}$ & $\%$ \\
\hline $1-3$ & 1 & 3 & 1 & 3 \\
\hline $4-6$ & 9 & 30 & 12 & 40 \\
\hline $7-10$ & 16 & 54 & 14 & 47 \\
\hline $11-14$ & 4 & 13 & 3 & 10 \\
\hline $25-30$ & 3 & 10 & 8 & 27 \\
\hline $31-36$ & 6 & 20 & 2 & 8 \\
\hline Total & $\mathbf{3 0}$ & & $\mathbf{3 0}$ & \\
\hline Mean & $7.68 \pm 2.57$ & $7.30 \pm 2.64$ \\
\hline \multicolumn{7}{|c}{ Table III: Showing Weight Range in $\mathbf{~} \boldsymbol{r}$} \\
\hline
\end{tabular}

\begin{tabular}{|c|c|c|c|c|}
\hline $\begin{array}{c}\text { Induction } \\
\text { Time In Sec. }\end{array}$ & $\begin{array}{c}\text { Group S } \\
\text { Nof } \\
\text { Patients }\end{array}$ & $\mathbf{\%}$ & $\begin{array}{c}\text { No. of } \\
\text { Patients }\end{array}$ & $\mathbf{\%}$ \\
\hline $180-210$ & 16 & 53 & -- & -- \\
\hline $210-240$ & 14 & 47 & 4 & 12 \\
\hline $240-270$ & -- & -- & 13 & 39 \\
\hline $270-300$ & -- & -- & 13 & 39 \\
\hline Total & $\mathbf{3 0}$ & & $\mathbf{3 0}$ & \\
\hline Mean time & $210 \pm 17$ secs & $262 \pm 21$ secs \\
\hline Table IV: Showing Distribution According to Induction \\
Time \\
\hline
\end{tabular}

\begin{tabular}{|c|c|c|c|c|}
\hline \multirow{2}{*}{$\begin{array}{c}\text { Intubating } \\
\text { Conditions }\end{array}$} & $\begin{array}{c}\text { Group S } \\
\text { No. of } \\
\text { Patients }\end{array}$ & $\mathbf{\%}$ & $\begin{array}{c}\text { Group Ho. of } \\
\text { Patients }\end{array}$ & $\%$ \\
\hline Excellent & 27 & 90 & 25 & 84 \\
\hline Good & 2 & 7 & 4 & 13 \\
\hline Fair & 1 & 3 & 1 & 3 \\
\hline Poor & -- & -- & -- & -- \\
\hline Total & $\mathbf{3 0}$ & -- & $\mathbf{3 0}$ & -- \\
\hline \multicolumn{4}{|c|}{ Table V: Showing Intubating Conditions } \\
\hline
\end{tabular}

\begin{tabular}{|c|c|c|}
\hline Time Interval & Group S & Group H \\
\hline After Premedication & $127.63 \pm 9.91$ & $129.86 \pm 9.81$ \\
\hline During Intubation & $118.96 \pm 9.86$ & $113.13 \pm 9.56$ \\
\hline After Intubation & $133.86 \pm 10.74$ & $126.06 \pm 8.28$ \\
\hline 1 minute after intubation & $130.86 \pm 9.66$ & $127.06 \pm 8.71$ \\
\hline $\begin{array}{c}\text { 2 minutes after } \\
\text { intubation }\end{array}$ & $128.86 \pm 10.97$ & $127.56 \pm 9.46$ \\
\hline $\begin{array}{c}\text { 3 minutes after } \\
\text { intubation }\end{array}$ & $129.53 \pm 11.53$ & $127.73 \pm 10.50$ \\
\hline \multicolumn{3}{|c|}{ Table VI: Showing Changes in Mean Pulse Rate } \\
\hline \multicolumn{3}{|c}{} \\
\hline
\end{tabular}




\begin{tabular}{|c|c|c|}
\hline \multirow[t]{2}{*}{ Time Interval } & \multicolumn{2}{|c|}{$\begin{array}{l}\text { Mean Systolic Blood } \\
\text { Pressure in } \mathrm{mm} \text { of } \mathrm{Hg}\end{array}$} \\
\hline & Group S & Group H \\
\hline After Premedication & $90.73 \pm 8.19$ & $90.08 \pm 7.94$ \\
\hline During Intubation & $86.36 \pm 7.98$ & $80.66 \pm 6.65$ \\
\hline After Intubation & $99.80 \pm 7.66$ & $96.0 \pm 6.38$ \\
\hline 1 minute after Intubation & $94.76 \pm 7.19$ & $92.6 \pm 5.99$ \\
\hline 2 minutes after Intubation & $93.73 \pm 7.14$ & $92.4 \pm 5.97$ \\
\hline 3 minutes after Intubation & $93.13 \pm 6.78$ & $91.86 \pm 5.27$ \\
\hline $\begin{array}{r}\text { Table VII: Showing Cha } \\
\mathrm{Pr}\end{array}$ & $\begin{array}{l}\text { in Mean S } \\
\text { re }\end{array}$ & lic Blood \\
\hline
\end{tabular}

\begin{tabular}{|c|c|c|}
\hline \multirow{2}{*}{ Time Interval } & \multicolumn{2}{|c|}{$\begin{array}{c}\text { Mean Arterial Blood Pressure in } \\
\text { mm of Hg }\end{array}$} \\
\cline { 2 - 3 } & Group S & Group H \\
\hline After Premedication & $56.7 \pm 4.41$ & $60.93 \pm 4.77$ \\
\hline During Intubation & $56.42 \pm 4.13$ & $57.99 \pm 3.98$ \\
\hline After Intubation & $66.58 \pm 5.52$ & $63.46 \pm 3.72$ \\
\hline $\begin{array}{c}\text { 1 minute after } \\
\text { intubation }\end{array}$ & $61.58 \pm 4.90$ & $61.21 \pm 3.35$ \\
\hline $\begin{array}{c}\text { 2 minutes after } \\
\text { intubation }\end{array}$ & $60.70 \pm 4.50$ & $61.15 \pm 3.15$ \\
\hline $\begin{array}{c}\text { 3 minutes after } \\
\text { intubation }\end{array}$ & $60.01 \pm 4.50$ & $60.57 \pm 2.71$ \\
\hline \multicolumn{2}{|c|}{ Table VIII: Showing Mean Arterial Blood Pressure } \\
\hline
\end{tabular}

\section{OBSERVATIONS}

These 60 paediatric patients were divided into 2 groups. The age distribution was as shown in Table No. I.

Mean age range in group $\mathrm{S}$ was $21 \pm 9$ months and group $\mathrm{H}$ was $18 \pm 9$ months. There was no significant difference as far as age range was concerned in both groups ( $\mathrm{p}$-value $=0.22$ ).

Distribution of patients according to sex was as shown in Table No. II.

There were $67 \%$ male in group $\mathrm{S}$ and $77 \%$ in group $\mathrm{H}$ while there were $33 \%$ female in group $\mathrm{S}$ and $23 \%$ in group $\mathrm{H}$.

The weight range in both groups was as shown in Table No. III.

Mean weight range was $7.68 \pm 2.57$ in group $S$ and $7.30 \pm 2.64$ in group $H$. There was no statistical significant difference in weight of both groups ( $p$-value $=0.87$ ).

The distribution of patients according to induction time in seconds was as noted in Table No. IV.

The induction time was within $180-210$ seconds in $53 \%$ of patients and $210-240$ secs in $47 \%$ in Sevoflurane group. In Halothane group, induction time was $210-240$ secs in $12 \%$, $240-270$ secs and $270-300$ secs in $39 \%$ of patients each. The mean induction time was $210 \pm 17$ secs. in Sevoflurane group and $262 \pm 21$ secs in Halothane group. Thus, induction time was significantly less in Sevoflurane group as compared to Halothane group ( $\mathrm{p}$-value=0.02). Sevoflurane offered quicker induction than Halothane in paediatric patients.

The distribution of patients according to intubating conditions observed were as shown in Table No. V.

In Sevoflurane group, $90 \%$ of patients had excellent intubating conditions while in Halothane group $84 \%$ of patients had excellent intubating conditions. Good intubating conditions were noted in $7 \%$ of patients in group S and $13 \%$ patients in group $\mathrm{H}$. Only one patient in each group had fair intubating conditions. So, the intubating conditions between two groups were not statistically significant ( $p$-value $=0.99$ ). Thus, intubating conditions were excellent in more number of patients of Sevoflurane group as compared to Halothane group.

The changes in mean pulse rate at various time intervals were noted as shown in Table No. VI.

After premedication, mean pulse rate was $127.63 \pm 9.91$ in group $S$ and $129.86 \pm 9.81$ in group H. During intubation, mean pulse rate was 118.96 in group $\mathrm{S}$ and $113.13 \pm 9.56$ in group $\mathrm{H}$. It was observed that mean pulse rate was significantly less in both groups during intubation as compared to premedication readings ( $p$-value $=0.03$ ). The mean pulse rate increased insignificantly in both groups after intubation and 1,2,3 minutes time intervals in both groups as compared to post premedication. The mean pulse rate remained low during intubation in both groups.

The changes in mean systolic blood pressure at various time intervals in both groups were as shown in Table No. VII.

After premedication, mean systolic blood pressure were $90.73 \pm 8.19 \mathrm{~mm}$ of $\mathrm{Hg}$ in group S and $90.08 \pm 7.94 \mathrm{~mm}$ of $\mathrm{Hg}$ in group H. There was significant fall in mean systolic blood pressure during intubation in both groups as compared to premedication readings ( $\mathrm{p}$-value $=0.007$ ). After intubation and at 1,2,3 minutes intervals, again there was insignificant increase in mean systolic blood pressure in both groups as compared to during intubation readings and also during premedication readings. Thus, during intubation, mean systolic blood pressure was significantly less as compared to premedication and after intubation readings in both groups.

The changes in mean arterial pressure were noted as shown in Table No. VIII.

After premedication, mean arterial blood pressure was $56.7 \pm 4.41 \mathrm{~mm}$ of $\mathrm{Hg}$ in group $\mathrm{S}$ and $60.93 \pm 4.77 \mathrm{~mm}$ of $\mathrm{Hg}$ in group $H$. There was insignificant decrease in mean arterial pressure during intubation readings in both groups ( $\mathrm{p}$ value $=0.11$ ). There was no significant difference in mean arterial pressure amongst two groups at various time intervals.

\section{DISCUSSION}

Since introduction of newer inhalational anaesthetic agents, it has become safe to practise anaesthesia. These contribute for advanced medical and healthcare for human population. General anaesthesia constitutes smooth induction, rapid endotracheal intubation, uneventful intra and postoperative outcome after operative procedures. Aspiration of gastric contents during laryngoscopy and intubation is a major contributing factor for anaesthetic morbidity and mortality. So, smooth induction and rapid endotracheal intubation is mandatory particularly in paediatric patients to avoid these complications.

Inhalational anaesthetic agents with potent action and smooth induction simplified technique of general anaesthesia. Halothane due to its high potency and smooth induction, easy passage into deep levels of anaesthesia by increasing concentration, sweet smell, and easy acceptance by paediatric patients remained agent of choice for many years. There is tendency for alkaline derivatives of Halothane to enhance dysrhythmogenic effects of epinephrine, which led to search of new inhalational agents particularly derived from esters. The introduction of fluorinated methyl isopropyl ester Sevoflurane having low solubility in blood facilitates rapid and smooth induction and smooth recovery. 
Meretoja O A et al (1996), ${ }^{3}$ Paris S T et al (1997), ${ }^{4}$ Brain K $O$ et al (1998), ${ }^{5}$ Sigston P E et al (1997), ${ }^{6}$ Black A et al (1996), ${ }^{7}$ and Vernoque et al (1994) ${ }^{8}$ have used Sevoflurane and Halothane in paediatric patients for endotracheal intubation. In the present study, the age range was 3 months to 3 years and the age range of above authors was corresponding to our study. Mean weight range was $7.68 \pm 2.64 \mathrm{~kg}$ in Group S and $7.30 \pm 2.64$ in group $H$. There was no statistical difference in both groups.

\section{Induction Time}

Meretoja O A et al (1996), ${ }^{3}$ Paris S T et al (1997), ${ }^{4}$ Brien K 0 et al (1998), ${ }^{5}$ Massakki et al (1993), ${ }^{9}$ Veronique et al (1994), ${ }^{8}$ Matsuyki et al (1993),10 Joel B et al (1995),11 Sigston et al (1997), ${ }^{6}$ Bkack A et al (1996), 7 and many others have used various inhalational anaesthetic agents such as Sevoflurane, Halothane, Enflurane, or Isoflurane for induction of anaesthesia in their paediatric patients. Many of them have noted that, induction time within 120-160 seconds for Sevoflurane and 180-240 secs for Halothane. In the present study, mean induction time was $210 \pm 8$ secs for Sevoflurane and $262 \pm 21$ secs for Halothane. Induction time was significantly less with Sevoflurane as compared to Halothane. The induction time was comparatively prolonged in the present study as the inspired concentration was low during the starting of induction in both groups as compared to other studies. Most of above authors have observed quicker induction time with Sevoflurane as compared to Halothane in their studies. Our observations coincides with above observations.

The slow induction of anaesthesia is mainly due to its high blood/gas coefficient (Krien K O et al, 1998). ${ }^{5}$ The induction of anaesthesia with inhalational anaesthetic agents depend on alveolar ventilation, cardiac output, and regional distribution as tissue/blood and blood/gas solubility coefficient (Veronique et al 1994). ${ }^{8}$ Sevoflurane has a low blood/gas solubility than Halothane, hence rapid induction, rapid recovery. Thus, sevoflurane is more potent than Halothane, hence induction is quicker with sevoflurane as compared to Halothane and our observations can be explained on above grounds.

\section{Intubating Conditions}

Brien K O et al (1998) ${ }^{5}$ used Helbo-Henson, Ralvo, and Trap Anderson. ${ }^{1}$ Scoring system to assess the intubating conditions in their study. In the present study, we have also assessed the intubating conditions with above system in our study. We have observed equivalent intubating conditions either with Sevoflurane and Halothane. We have noted 27 (90\%) out of 30 in Group S and 25 (84\%) out of 30 in group $\mathrm{H}$ had excellent intubating conditions. Masaki et al (1993),12 P E Sigston et al (1998),6 Black J E et al (1996),7 R C Agnor et al (1998)12 have also observed excellent intubating conditions in more number of patients with Sevoflurane as compared to Halothane induction. Sevoflurane has less airway irritation, more pleasant smell than Halothane, so more acceptance with rapid induction and deep level of anaesthesia than Halothane. So, more number of patients had excellent intubating conditions with Sevoflurane than Halothane.

\section{Heart Rate}

O A Meretoja et al (1996) ${ }^{3}$ observed cardiac arrhythmias more common in Halothane induction as compared to Sevoflurane anaesthesia. In our study, mean pulse rate decreased in Group $\mathrm{S}$ during intubation and increased after intubation. In Group $\mathrm{H}$, mean pulse rate was more decreased during intubation and increased after intubation. We observed Sevoflurane to be more cardio stable as compared to Halothane as far as mean pulse rate was concerned. Paris S T et al (1993), ${ }^{4}$ Brien K O, et al (1998), 5 Friesen R H et al (1982),13 Veronique et al (1994),8 and Sorner J B et al (1995) ${ }^{11}$ have also noted Sevoflurane to be cardio stable during intubation than Halothane. Our observations correlate with these authors. Cardio stability offered with Sevoflurane might be due to its non-myocardial depressant action, which is there with Halothane.

\section{Mean Arterial Pressure}

Friesen R H et al (1982), ${ }^{13}$ Epstein R H et al (1995),, ${ }^{14}$ Sarner J $B$ et al (1995), ${ }^{11}$ Shin Kawana et al (1995),15 Black A et al (1996), ${ }^{7}$ Brien K O et al (1998), 5 and H Vitanen (1999) ${ }^{16}$ have studied mean arterial pressure during induction and after intubation under Sevoflurane and Halothane anaesthesia. In the present study, in group $\mathrm{H}$, mean systolic blood pressure and mean arterial pressure decreased during intubation by 10 $\mathrm{mm}$ of $\mathrm{Hg}$ and increased after intubation. There are many variations as far as mean systolic and mean arterial pressure is concerned in different studies. These might be due to differences in age group of patients, MAC values, and concentrations of Sevoflurane and Halothane used for induction of anaesthesia. Overall, Sevoflurane offers more cardio stability due to less myocardial depressant action as compared to Halothane in paediatric patients.

\section{CONCLUSIONS}

From the present study, it was concluded that inhalational anaesthetic agents Sevoflurane and Halothane can be used for smooth induction and rapid endotracheal intubation. Sevoflurane has sweet smell, less airway irritation, and greater acceptance particularly by paediatric patients, so it is preferred over Halothane. Sevoflurane is more potent than Halothane. It provides excellent intubating conditions with cardiovascular stability in paediatric patients as compared to Halothane. So, it is better choice in paediatric patients for endotracheal intubation than Halothane.

\section{REFERENCES}

1. Helbo-Hansen, Ravlo O, Trap-Andersen S. The influence of alfentanil on intubating conditions after priming with vecuronium. Acta Anaesthesiologica Scandinavica 1988;32(1):41-44.

2. Steyn MP, Quinn AM, Gillespie JA, et al. Tracheal intubation without neuromuscular block in children. British Jr. Anaesth 1994;72(4):403-406.

3. Meretoja OA, Taivainen T, RaihaL, et al. Sevofluranenitrous oxide or halothane-nitrous oxide for paediatric bronchoscopy and gastroscopy. British Jr. Anaesth 1996;76:767-771.

4. Paris ST, Cafferkey M, Tarling M, et al. Comparison of sevoflurane and halothane for outpatient dental anaesthesia in children. British Jr Anaesth 1997;79:280284. 
5. O’Brien K, Kumar R, Morton NS, et al. Sevoflurane compared with halothane for tracheal intubation in children. British Jr. Anaesth 1998;80:452-455.

6. Sigston PE, Jenkins AMC, Jackson EA, et al. Rapid inhalation induction in children: $8 \%$ sevoflurane compared with 5\% halothane. British Jr. Anaesth 1997;78:362-365.

7. Black A, Sury MRJ, Hemington L, et al. A Comparison of the induction characteristics of sevoflurane and halothane in children. Anaesthesia 1996;51(6)539-542.

8. Veronique $\mathrm{P}$, Dubois $\mathrm{MC}$, Johanet $\mathrm{S}$, et al. Induction and recovery characteristics and haemodynamic responses to sevoflurane and halothane in children. Anaesth Analg 1994;79(5):840-844.

9. Yurina $M$, Kimura $H$. Induction of anaesthesia with sevoflurane, nitrous oxide, and oxygen, a comparison of spontaneous ventilation and vital capacity rapid inhalation induction techniques. Anaesth Analg 1993;76(3):598-601.

10. Doi M, Ikeda K, et al. Airway irritation produced by volatile anaesthetics during brief inhalation: comparison of halothane, enflurane, isoflurane, and sevoflurane. Can J of Anaesth 1993;40(2):122-126.
11. Sarner JB, Levine M, Davis PJ, et al. Clinical characteristics of sevoflurane in children. A comparison with halothane. Anaesthesiology 1995;82(1):38-46.

12. Agnor RC, Sikich N, Lerman J, et al. Single breath vital capacity rapid induction in children, 8\% Sevoflurane versus 5\% halothane. Anaesthesiology 1998;89:379-384.

13. Friesen RH, Lichtor JL. Cardiovascular depression during halothane anaesthesia in infants-a study of three induction techniques. Anaesth and Anal 1982;61(1):42-45.

14. Epstein RH, Mendel HG, Guarnieri KM, et al. Sevoflurane versus halothane for general anaesthesia in paediatric patients-a comparative study of vital signs, induction, and emergence. J of Clinical Anaesthesia 1995;7(3):237-244.

15. Kawana S, Wachi J, Nakayama M, et al. Comparison of haemodynamic changes induced by sevoflurane and halothane in paediatric patients. Can J of Anaesth 1995;42(7):603-607.

16. Viitanen H, Baer G, Koivu H, et al. The haemodynamic and Holter-electrocardiogram changes during halothane and sevoflurane anaesthesia for adenoidectomy in children aged 1-3 years. Anaesth Analg 1999;89(6):1423-1425. 